\title{
Perilaku Harian dan Profil Demografi Mempengaruhi Kenaikan Tagihan Listrik Selama Covid-19 di Indonesia: Pendekatan SEM-PLS
}

\author{
Rosyid R. Al Hakim \\ Jurusan Teknik Elektro, FTIK, Universitas Global Jakarta, Depok, Indonesia \\ Email: rosyidridlo10@gmail.com
}

\begin{abstract}
The Covid-19 pandemic has impacted the use of electrical energy in households. There have been reports of changes in electrical energy consumption before and during the Covid-19 pandemic in several countries. This study aims to review the daily behavior activities and demographic profile of Indonesia's population regarding rising electricity bills during the Covid19 pandemic through the Structural Equation Modeling-Partial Least Square (SEM-PLS) approach. The research method uses the Structural Equation Modeling-Partial Least Square (SEM-PLS) approach. A total of 137 respondents are assumed to have experienced the impact of rising electricity bills during the Covid-19 pandemic in Indonesia. This study proposes four hypotheses to be tested through the SEM-PLS approach. A total of two hypotheses were accepted, and two hypotheses were rejected. Hypothesis $\mathrm{H} 1$ (p-value < 0.05 ) so that $\mathrm{H} 1$ is obtained or there is a relationship between daily behavioral activities and increased electricity bills. Hypothesis $H 3$ ( $p$-value < 0.05) so that $H 3$ is accepted or a connection between the respondent's profile and the increase in electricity bills. Meanwhile, additional devices that require electric power and the number of electric pulses purchased have no relationship to the rise in electricity bills during the Covid-19 pandemic in Indonesia.
\end{abstract}

Keywords: Activity, Energy, Pandemic, Partial Least Square, Structural Equation Modeling.

\begin{abstract}
Abstrak
Pandemi Covid-19 telah berdampak pada penggunaan energi listrik di rumah tangga. Dilaporkan terjadi perubahan konsumsi energi listrik sebelum dan selama pandemi Covid-19 di beberapa negara. Penelitian ini bertujuan untuk me-review aktivitas perilaku sehari-hari dan profil demografi penduduk di Indonesia terhadap kasus naiknya tagihan listrik selama pandemi Covid-19 melalui pendekatan Structural Equation Modeling-Partial Least Square (SEM-PLS). Metode penelitian menggunakan pendekatan Structural Equation Modeling-Partial Least Square (SEM-PLS). Sebanyak 137 responden yang diasumsi mengalami dampak kenaikan tagihan listrik selama pandemi Covid-19 di Indonesia. Terdapat empat hipotesis yang diajukan dalam studi ini untuk diuji melalui pendekatan SEM-PLS. Sebanyak dua hipotesis diterima dan dua hipotesis ditolak. Hipotesis $\mathrm{H} 1$ ( phitung $_{2} 0.05$ ) sehingga $\mathrm{H} 1$ diterima atau terdapat hubungan antara aktivitas perilaku harian terhadap kenaikan tagihan listrik. Hipotesis $\mathrm{H} 3$ ( phitung $_{2}<0.05$ ) sehingga $\mathrm{H} 3$ diterima atau terdapat hubungan antara profil responden terhadap kenaikan tagihan listrik. Sedangkan perangkat tambahan yang memerlukan daya listrik dan besar pulsa listrik yang dibeli tidak terdapat hubungan terhadap kenaikan tagihan listrik selama pandemi Covid-19 di Indonesia.
\end{abstract}

Kata Kunci: Aktivitas, Energi, Pandemi, Partial Least Square, Structural Equation Modeling.

\section{PENDAHULUAN}

Perilaku penggunaan energi listrik berperan penting dalam menunjang strategi intervensi, khususnya bagi negara-negara yang belum berkategori negara maju. Perilaku penggunaan energi listrik dilaporkan sebelumnya di negara Afrika Selatan berkorelasi dengan pekerjaan dan 
tingkat pendapatan setiap keluarga. Semakin rendah semakin berpotensi menggunakan energi listrik yang tidak sebanding dengan pendapatan tetap setiap keluarga [1]. Laporan sebelumnya mencatat di Indonesia terdapat pola aktivitas harian yang menyebabkan kenaikan tagihan listrik di setiap bulannya [2].

Penelitian lain melaporkan perilaku penggunaan energi listrik rumah tangga dengan pendapatan tetap yang cukup tinggi di Afrika Selatan. Terbukti kurang dari $50 \%$ dari total data responden berperilaku boros listrik, meskipun dijumpai perilaku menghemat listrik, namun hal ini menjadi bukti bahwa perlunya meningkatkan kesadaran akan penghematan energi listrik untuk mendukung perilaku ramah lingkungan [3]. Kajian mengenai perilaku harian dan profil demografi penduduk terhadap potensi naiknya tagihan listrik yang didapatkan sangat menarik untuk diteliti lebih lanjut, khususnya di negara-negara berkembang. Temuan menarik lainnya, selama pandemi Covid-19, dilaporkan terjadi perubahan konsumsi energi listrik pada skala rumah tangga [4]-[8].

Di Indonesia, dilaporkan pula masyarakat mengeluh akan naiknya tagihan listrik, terutama selama pekerjaan berlangsung secara work from home (WFH) [2]. Perilaku akan pentingnya menghemat energi listrik sangat penting, terutama terhadap perilaku sehari-hari dan umumnya pada penduduk dengan usia dewasa hingga tua, karena umumnya mereka yang berurusan dengan tagihan listrik [9]. Studi ini bertujuan untuk menganalisis aktivitas perilaku sehari-hari dan profil demografi penduduk di Indonesia terhadap kasus naiknya tagihan listrik selama pandemi Covid-19 melalui pendekatan Structural Equation Modeling-Partial Least Square (SEM-PLS).

\section{METODE PENELITIAN}

\subsection{Sampel Penelitian}

Data yang digunakan pada penelitian ini merupakan data kuesioner yang memuat profil demografi, aktivitas perilaku sehari-hari dalam menggunakan listrik, penggunaan pulsa listrik bagi pelanggan prabayar, perangkat tambahan yang memerlukan daya listrik, dan tingkat kenaikan tagihan listrik selama pandemi Covid-19. Data responden didapatkan dari penelitian sebelumnya [2], sehingga dalam studi ini merupakan studi review terhadap data responden yang dicoba diketahui hubungan antar-variabel terhadap kenaikan tagihan listrik selama pandemi Covid-19 melalui pendekatan Structural Equation Modeling-Partial Least Square (SEM-PLS).

Variabel yang digunakan dalam penelitian ini antara lain profil demografi, dependent variable (endogenous variable), dan independent variable (exogenous variable). Profil demografi memuat data pekerjaan, umur, dan jenis kelamin. Endogenous variable dalam penelitian ini adalah profil responden, aktivitas perilaku harian, besar pulsa listrik yang dibeli, dan perangkat tambahan yang memerlukan daya listrik. Exogenous variable dalam penelitian ini adalah kenaikan tagihan listrik, yang terdiri atas indikator kurangnya jumlah pulsa listrik yang dibeli dan indikator besarnya kenaikan tagihan listrik.

Populasi penelitian yang digunakan adalah penduduk yang tinggal di beberapa wilayah di Indonesia dengan rentang umur antara 18 hingga 70 tahun, di mana sampel yang digunakan dalam penelitian ini sejumlah 137 orang responden. Data kuesioner melalui google form secara daring [2]. Teknik pengambilan sampel yang digunakan adalah random sampling, dengan kriteria responden merupakan pelanggan listrik dari PLN baik prabayar atau pasca bayar dan mengalami kenaikan tagihan listrik selama pandemi Covid-19.

\subsection{Instrumen Penelitian}

Variabel yang digunakan dalam penelitian ini antara lain profil demografi, dependent variable (endogenous variable), dan independent variable (exogenous variable). Profil demografi memuat data pekerjaan, umur, dan jenis kelamin.

Endogenous variable dalam penelitian ini adalah profil responden (terdiri atas indikator identitas responden, indikator rentang umur, dan indikator jenis pekerjaan), aktivitas perilaku harian (terdiri atas indikator perilaku yang menyebabkan kenaikan tagihan listrik, perilaku menggunakan listrik, jumlah daya listrik yang terpasang), besar pulsa listrik yang dibeli (terdiri atas indikator pulsa prabayar dan indikator tagihan listrik pasca bayar), dan perangkat tambahan yang memerlukan daya listrik (terdiri atas indikator penambahan WiFi dan indikator penambahan TV kabel). 
Exogenous variable dalam penelitian ini adalah kenaikan tagihan listrik, yang terdiri atas indikator kurangnya jumlah pulsa listrik yang dibeli dan indikator besarnya kenaikan tagihan listrik. Hal ini berkaitan dengan kasus kenaikan tagihan listrik yang kemungkinan dipengaruhi oleh faktor perilaku sehari-hari, profil demografi terutama pada pekerjaan dan umur, serta besarnya pulsa listrik atau tagihan listrik setiap bulannya.

Semua indikator dalam variabel diberi simbol. Setiap indikator membentuk konstruk (construct) variabel laten. Tabel 1 merupakan simbol setiap indikator dan tipe variabel.

Tabel 1. Definisi variabel penelitian.

\begin{tabular}{lcc}
\hline \multicolumn{1}{c}{ Indikator } & Notasi & Tipe Variabel \\
\hline Profil responden & PF & Latent Variable \\
Identitas responden & PF1 & Manifest Variable \\
Rentang umur & PF2 & Manifest Variable \\
Jenis pekerjaan & PF3 & Manifest Variable \\
Aktivitas perilaku harian & AK & Latent Variable \\
Perilaku yang menyebabkan kenaikan tagihan listrik & AK1 & Manifest Variable \\
Perilaku menggunakan listrik & AK2 & Manifest Variable \\
Jumlah daya listrik yang terpasang & AK3 & Manifest Variable \\
Besar pulsa listrik yang dibeli & PL & Latent Variable \\
Pulsa prabayar & PL1 & Manifest Variable \\
Tagihan listrik pasca bayar & PL2 & Manifest Variable \\
Perangkat tambahan yang memerlukan daya listrik & PT & Latent Variable \\
Penambahan WiFi & PT1 & Manifest Variable \\
Penambahan TV kabel & PT2 & Manifest Variable \\
Kenaikan tagihan listrik & TG & Latent Variable \\
Kurangnya jumlah pulsa listrik yang dibeli & TG1 & Manifest Variable \\
Besarnya kenaikan tagihan listrik & TG2 & Manifest Variable \\
\hline
\end{tabular}

\subsection{Metodologi}

Metode yang digunakan dalam penelitian ini adalah pendekatan secara Structural Equation Modeling-Partial Least Square (SEM-PLS). SEM merupakan salah satu teknik pemodelan dalam statistik analisis covariance dengan fitur cross-sectional statistics secara model linear dan model general. SEM terdiri atas pemodelan analisis faktor (factor analysis), analisis jalur (path analysis), regresi (regression), dan pertumbuhan curve pada pemodelan latent variable [10].

Analisis statistik melalui pendekatan SEM-PLS diawali dari analisis statistika deskriptif dan uji normalitas data berdasarkan construct dan indikator (item code) pada penelitian ini, sehingga didapatkan nilai uji Skewness-Kurtosis. Selanjutnya, pemodelan PLS-path awal untuk kemudian menjalankan PLS-algorithm, apabila nilai loading factor indikator ditemukan di bawah 0.6 maka indikator tersebut akan dihapus dan dilakukan analisis PLS-algorithm kembali hingga seluruh nilai loading factor indikator bernilai $\geq 0.6$ dan didapatkan pemodelan PLS-path hasil modifikasi, karena penelitian ini termasuk jenis exploratory research [11], [12]. Selanjutnya, analisis nilai convergent validity and realibility, nilai discriminant validity: Heterotrait-Monotrait Ratio (HTMT), nilai discriminant validity: Fornell and Larcker Criterion. Hasil akhir berupa ringkasan pengujian hipotesis berdasarkan pendekatan SEM.

Hipotesis penelitian ini terdiri atas:

1) Terdapat hubungan antara aktivitas perilaku harian terhadap kenaikan tagihan listrik.

2) Terdapat hubungan antara perangkat tambahan yang memerlukan daya listrik terhadap kenaikan tagihan listrik.

3) Terdapat hubungan antara profil responden terhadap kenaikan tagihan listrik.

4) Terdapat hubungan antara besar pulsa listrik yang dibeli terhadap kenaikan tagihan listrik.

Keempat hipotesis akan dilakukan uji hipotesis melalui program bootstrapping yang dilakukan setelah evaluasi model pengukuran SEM-PLS dilakukan.

\section{HASIL DAN PEMBAHASAN}

\subsection{Profil Demografi}

Dari 137 responden kuesioner yang didapatkan, data responden dibagi dalam kategori pekerjaan, umur (dalam tahun) dan jenis kelamin. Kategori pekerjaan terdiri atas 9 jenis 
pekerjaan dengan jumlah terbanyak responden bekerja sebagai karyawan swasta $(n=33)$ disusul PNS $(n=31)$, sedangkan pekerjaan paling sedikit adalah peneliti $(n=4)$. Kategori umur dibagi dalam interval umur di bawah 25 tahun (<25), 25-35 tahun, 36-50 tahun, 51-70 tahun. Responden terbanyak berumur pada interval $36-50$ tahun $(n=62)$. Kategori jenis kelamin terdiri atas laki-laki dan perempuan, dengan jumlah responden terbanyak berjenis kelamin laki-laki $(\mathrm{n}=78)$. Tabel 2 memaparkan profil demografi responden pada penelitian ini.

Tabel 2. Profil demografi responden.

\begin{tabular}{|c|c|c|}
\hline Profil Demografi & Jumlah & $\%$ \\
\hline \multicolumn{3}{|l|}{ Pekerjaan } \\
\hline Buruh & 8 & $5.84 \%$ \\
\hline Freelancer & 11 & $8.03 \%$ \\
\hline Guru/Pengajar Non-PNS & 15 & $10.95 \%$ \\
\hline Karyawan Swasta & 33 & $24.09 \%$ \\
\hline Pedagang & 8 & $5.84 \%$ \\
\hline PNS & 31 & $22.63 \%$ \\
\hline Peneliti & 4 & $2.92 \%$ \\
\hline Petani & 10 & $7.30 \%$ \\
\hline Wirausaha & 17 & $12.41 \%$ \\
\hline \multicolumn{3}{|l|}{ Umur (Tahun) } \\
\hline$<25$ & 21 & $15.33 \%$ \\
\hline $25-35$ & 31 & $22.63 \%$ \\
\hline $36-50$ & 62 & $45.26 \%$ \\
\hline $51-70$ & 23 & $16.79 \%$ \\
\hline \multicolumn{3}{|l|}{ Jenis Kelamin } \\
\hline Laki-laki & 78 & $56.93 \%$ \\
\hline Perempuan & 59 & $43.07 \%$ \\
\hline Total Data & 137 & $100.00 \%$ \\
\hline
\end{tabular}

Berdasarkan Tabel 2, responden pada penelitian ini didominasi bekerja sebagai karyawan swasta dengan rentang umur antara 36-50 tahun dengan jenis kelamin laki-laki. Penelitian [9] juga melibatkan responden dengan rentang umur sekitar 25 hingga umur di atas 60 tahun, dalam hal ini karena mereka tercatat sering melakukan pembayaran tagihan listrik, sehingga profil demografi responden pada penelitian ini memang terbukti sering melakukan pembayaran tagihan listrik secara rutin.

\subsection{Statistika Deskriptif dan Uji Normalitas Data}

Analisis statistika deskriptif dan uji normalitas data terhadap 137 responden penelitian dilakukan untuk mengetahui normalitas data responden. Uji normalitas merupakan pengujian awal yang dilakukan sebelum melakukan analisis lebih lanjut [13]. Tabel 3 menjelaskan hasil analisis statistika deskriptif dan uji normalitas data.

Tabel 3. Statistika deskriptif dan hasil uji normalitas data.

\begin{tabular}{cccccccc}
\hline Construct & Item Code & Min & Max & Mean & Standard Deviation & Excess Kurtosis & Skewness \\
\hline \multirow{2}{*}{ PF } & PF1 & 1 & 5 & 3.569 & 0.942 & -0.230 & 0.062 \\
& PF2 & 1 & 5 & 4.139 & 0.945 & 1.166 & -1.122 \\
& PF3 & 1 & 5 & 3.693 & 0.993 & 0.474 & -0.661 \\
AK & AK1 & 1 & 5 & 3.066 & 0.881 & 0.992 & -0.129 \\
& AK2 & 2 & 5 & 4.569 & 0.577 & 1.712 & -1.198 \\
& AK3 & 1 & 5 & 3.277 & 0.902 & 0.508 & 0.084 \\
TG & TG1 & 1 & 5 & 3.204 & 0.838 & 1.195 & 0.423 \\
\hline \multicolumn{7}{c}{ Lisensi: Creative Commons Attribution 4.0 International (CC BY 4.0) } \\
\hline
\end{tabular}




\begin{tabular}{|c|c|c|c|c|c|c|c|}
\hline & TG2 & 1 & 5 & 3.679 & 0.879 & 0.299 & -0.233 \\
\hline \multirow[t]{2}{*}{ PL } & PL1 & 1 & 5 & 3.511 & 0.929 & -0.383 & 0.520 \\
\hline & PL2 & 1 & 5 & 3.949 & 1.069 & -0.084 & -0.694 \\
\hline \multirow[t]{2}{*}{ PT } & PT1 & 1 & 5 & 3.394 & 0.923 & 0.281 & 0.315 \\
\hline & РT2 & 1 & 5 & 3.723 & 0.877 & -0.822 & 0.248 \\
\hline
\end{tabular}

Berdasarkan Tabel 3, apabila nilai uji Skewness-Kurtosis tidak melebihi 2.000 maka dapat dikatakan distribusi data mendekati normal [13], dan pada hasil uji normalitas data penelitian ini semua nilai uji Skewness-Kurtosis berada di bawah nilai $2.000(<2.000)$ sehingga dapat dikatakan distribusi data responden penelitian ini mendekati normal dan analisis selanjutnya dapat dilakukan, yakni pemodelan SEM-PLS.

\subsection{Pemodelan SEM-PLS}

Seluruh construct yang merupakan latent variable dan item code yang merupakan indikator atau manifest variable pada penelitian ini dirancang pemodelannya secara structural equation modeling-partial least square (SEM-PLS). Latent variable profil (profil responden), aktivitas (aktivitas perilaku harian), pulsa listrik (besar pulsa listrik yang dibeli), dan perangkat tambahan (perangkat tambahan yang memerlukan daya listrik), serta tagihan (kenaikan tagihan listrik) disusun secara reflektif terhadap masing-masing item code atau manifest variable. Model PLSpath merupakan awal dari analisis SEM-PLS untuk mengetahui nilai loading factor dari setiap path antar-variabel. Gambar 1 merupakan model PLS-path awal ketika semua construct telah dirancang.

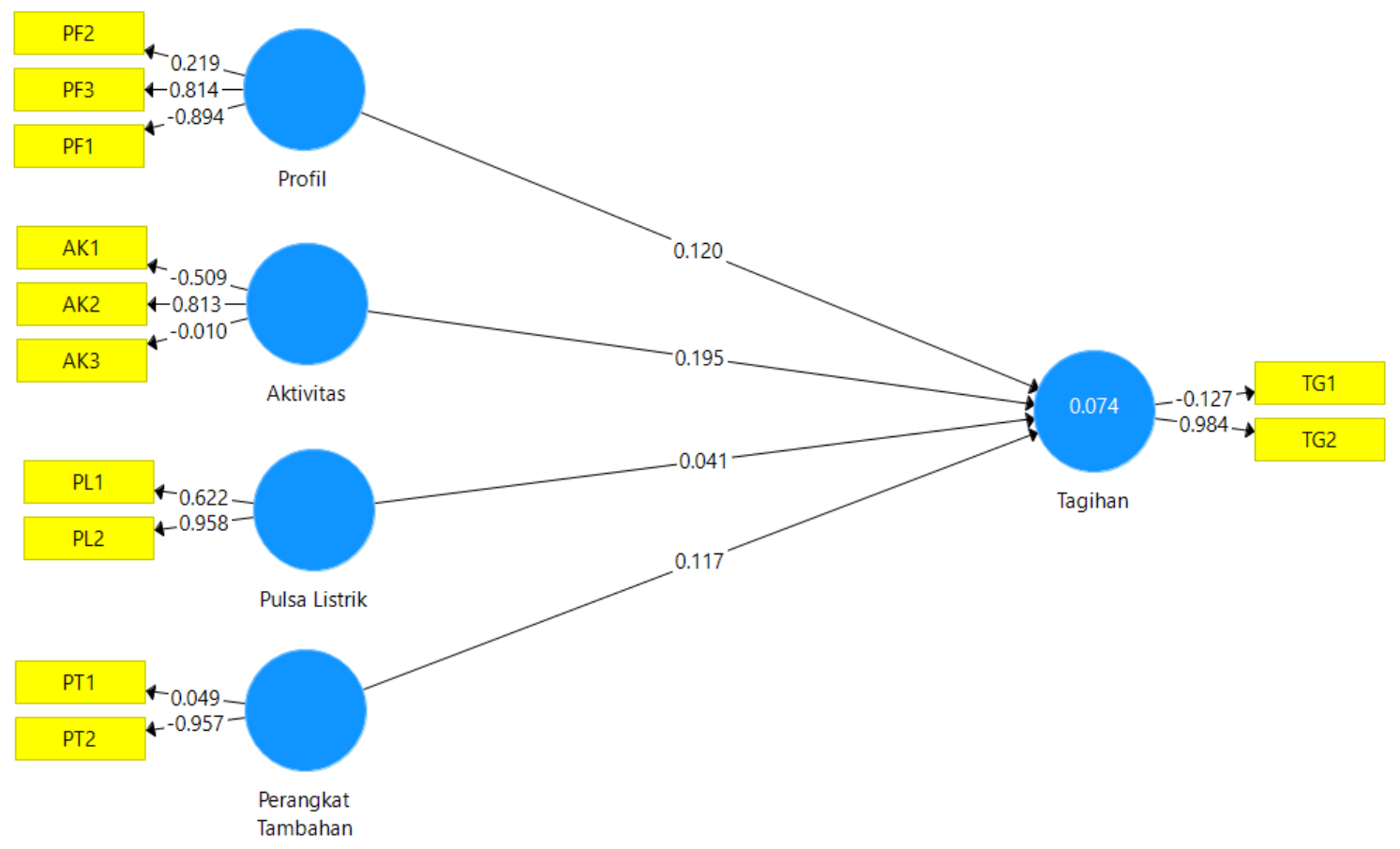

Gambar 1. Model PLS-path awal.

Setelah PLS-path awal berhasil dimodelkan, analisis dilanjutkan dengan menjalankan PLSalgorithm, sehingga didapatkan nilai path coefficient antar-construct dan nilai loading factor. Apabila nilai loading factor didapati kurang dari $0.60(<0.60)$ maka model PLS-path diseleksi kembali untuk menghilangkan manifest variable yang mempunyai nilai loading factor $<0.60$ [10]-[12], [14]-[18]. Gambar 1 dan Gambar 2 merupakan hasil penghilangan beberapa manifest variable yang mempunyai nilai loading factor $<0.60$. 


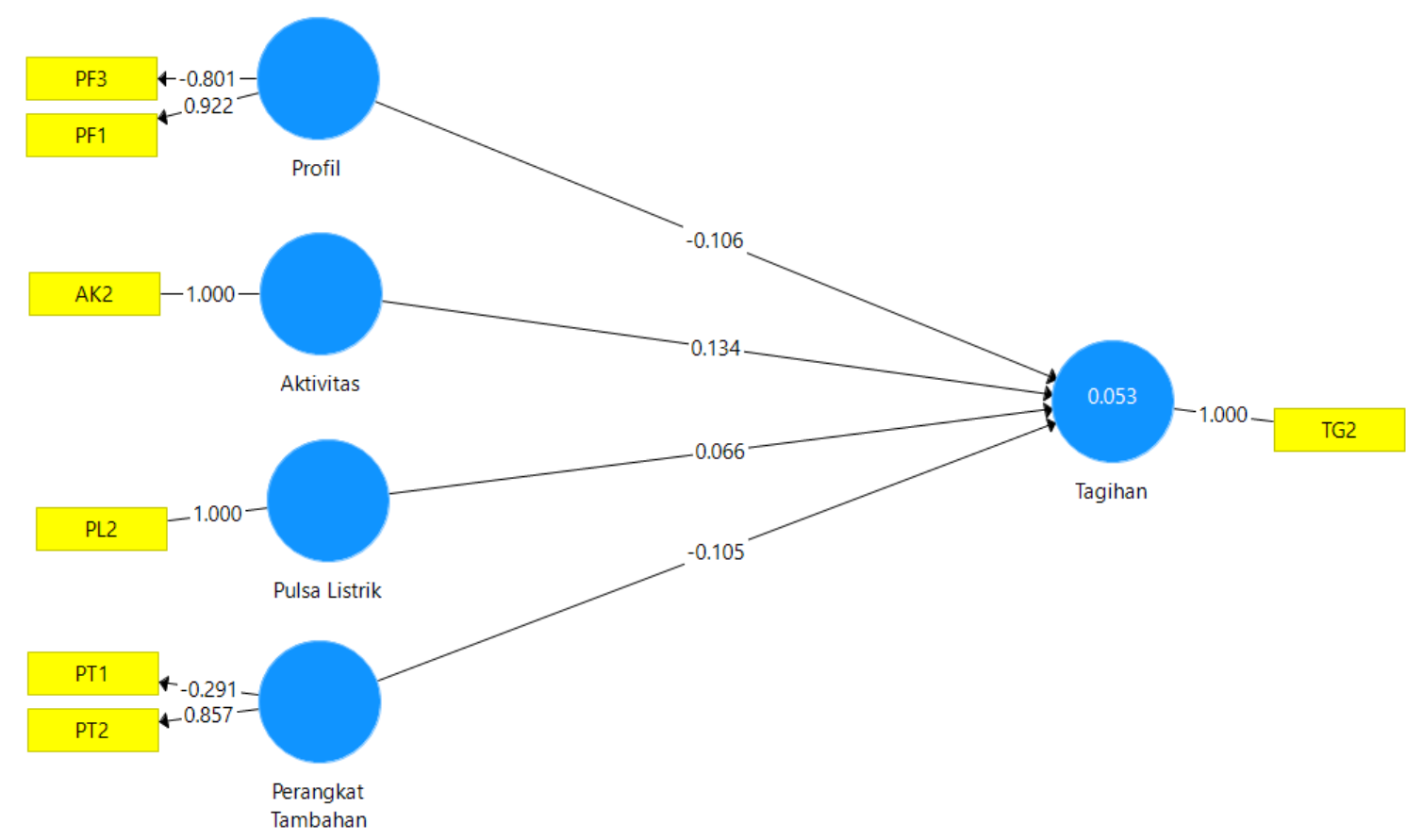

Gambar 2. Model PLS-path hasil modifikasi pertama.

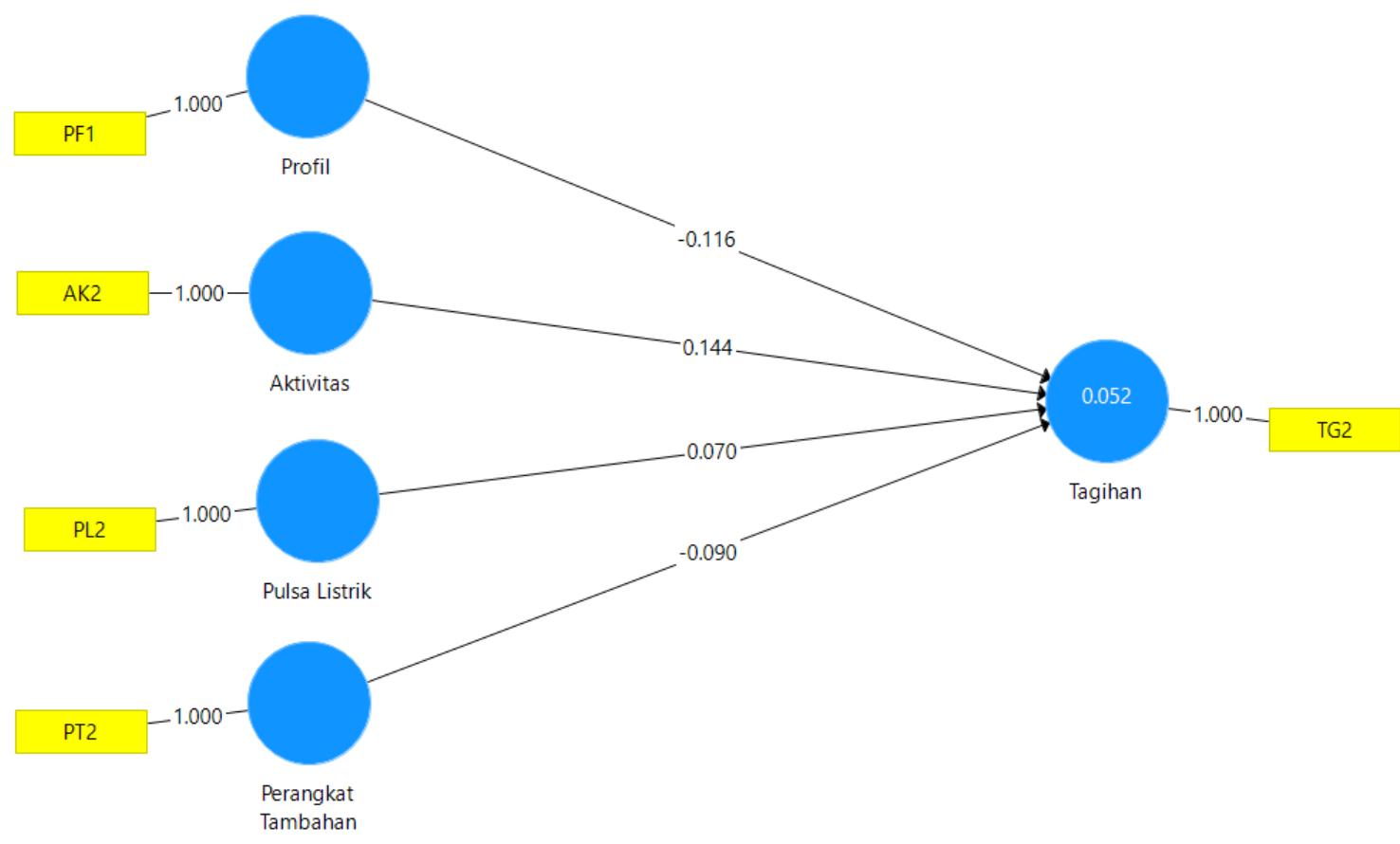

Gambar 3. Model PLS-path hasil modifikasi akhir.

Gambar 3 merupakan model PLS-path hasil modifikasi akhir yang final. Seluruh nilai loading factor pada outer loading berada pada nilai $>0.06$. Nilai path coefficient pada inner model apabila bernilai semakin mendekati +1 maka hubungan kedua construct semakin kuat [19], dalam hal ini antara construct aktivitas-tagihan dan pulsa listrik-tagihan hubungannya cukup sedang. Sebaliknya, nilai path coefficient pada inner model apabila bernilai semakin mendekati -1 maka hubungan kedua construct bersifat negatif [19], dalam hal ini antara construct profil-tagihan dan perangkat tambahan-tagihan. Tabel 4 menjelaskan nilai convergent validity and realibility (Composite Reliability; CR dan Average Variance Extracted; AVE) untuk setiap item code pada construct. 
Tabel 4. Nilai convergent validity and realibility.

\begin{tabular}{ccccc}
\hline Construct & Item Code & Outer Loading & CR & AVE \\
\hline PF & PF1 & 1.000 & 1.000 & 1.000 \\
AK & AK2 & 1.000 & 1.000 & 1.000 \\
TG & TG2 & 1.000 & 1.000 & 1.000 \\
PL & PL2 & 1.000 & 1.000 & 1.000 \\
PT & PT2 & 1.000 & 1.000 & 1.000 \\
\hline
\end{tabular}

Berdasarkan Tabel 4, evaluasi model pengukuran pada validitas dan reliabilitas untuk validitas convergent, parameter AVE sudah bernilai > 0.50, sehingga model pengukuran dinyatakan valid. Sedangkan untuk reliabilitas, parameter CR sudah bernilai $>0.60$ sehingga masih dapat diterima [10]-[12], [14]-[18]. Evaluasi model pengukuran untuk validitas discriminant dapat dilihat pada Tabel 5.

Tabel 5. Nilai discriminant validity: Heterotrait-Monotrait Ratio (HTMT).

\begin{tabular}{lllllll}
\hline & AK & PT & PF & PL & TG \\
\hline AK & & & & & & \\
PT & 0.077 & & & & & \\
PF & 0.073 & 0.021 & & & \\
PL & 0.000 & 0.101 & 0.029 & & \\
TG & 0.159 & 0.106 & 0.123 & 0.076 & \\
\hline
\end{tabular}

Berdasarkan Tabel 5, evaluasi model pengukuran pada validitas discriminant, parameter HTMT sudah bernilai < 0.90 sehingga model dinyatakan valid [10]-[12], [14]-[18]. Sedangkan untuk parameter Fornell and Larcker Criterion dapat dilihat pada Tabel 6.

Tabel 6. Nilai discriminant validity: Fornell and Larcker Criterion.

\begin{tabular}{cccccc}
\hline & AK & PT & PF & PL & TG \\
\hline AK & $\mathbf{1 . 0 0 0}$ & & & & \\
PT & -0.077 & $\mathbf{1 . 0 0 0}$ & & & \\
PF & -0.073 & -0.021 & $\mathbf{1 . 0 0 0}$ & & \\
PL & 0.000 & -0.101 & 0.029 & $\mathbf{1 . 0 0 0}$ & \\
TG & 0.159 & -0.106 & -0.123 & 0.076 & $\mathbf{1 . 0 0 0}$ \\
\hline
\end{tabular}

Catatan: Nilai diagonal ter-bold berasal dari akar kuadrat nilai AVE, nilai diagonal lainnya adalah koefisien korelasi antar latent construct.

Berdasarkan Tabel 6, semua nilai diagonal yang dicetak tebal (bold) sudah bernilai lebih besar dari koefisien korelasi antar latent construct, sehingga kondisi demikian dapat dinyatakan model pengukuran valid [10]-[12], [14]-[18]. Evaluasi pengukuran model struktural pada inner model, didapatkan nilai koefisien determinasi $\left(\mathrm{R}^{2}\right)$ sebesar 0.052 atau kriteria lemah pada construct tagihan. Dari hasil evaluasi model pengukuran inilah dilakukan analisis bootstrapping untuk menguji hipotesis penelitian. Tabel 7 merupakan ringkasan dari hasil pengujian keempat hipotesis pada penelitian ini.

Tabel 7. Ringkasan hasil pengujian hipotesis.

\begin{tabular}{cccccccccc}
\hline Hipotesis & Jalur & $\begin{array}{c}\text { Standar } \\
\text { Deviasi }\end{array}$ & $\mathrm{f}^{2}$ & thitung & phitung & Bias & \multicolumn{2}{c}{$\begin{array}{c}\text { Selang } \\
\text { Kepercayaan }\end{array}$} & Keputusan \\
& & & & & & & $5.00 \%$ & $95.00 \%$ & \\
\hline H1 & AK $>$ TG & 0.079 & 0.022 & 1.822 & 0.035 & 0.004 & -0.003 & 0.259 & Diterima \\
H2 & PT -> TG & 0.077 & 0.008 & 1.178 & 0.120 & 0.010 & -0.216 & 0.028 & Ditolak \\
H3 & PF -> TG & 0.070 & 0.014 & 1.656 & 0.049 & -0.002 & -0.242 & -0.001 & Diterima \\
H4 & PL $>>$ TG & 0.095 & 0.005 & 0.74 & 0.230 & -0.005 & -0.099 & 0.217 & Ditolak \\
\hline
\end{tabular}

Catatan: Phitung $\leq 0.05$ (1-tailed test). 
Berdasarkan Tabel 7, pengujian hipotesis terhadap empat hipotesis yang diajukan dalam penelitian ini adalah sebanyak dua hipotesis diterima dan dua hipotesis ditolak. Hipotesis $\mathrm{H} 1$ menghasilkan nilai phitung $<0.05$ sehingga $\mathrm{H} 1$ diterima atau terdapat hubungan antara aktivitas perilaku harian terhadap kenaikan tagihan listrik. Hipotesis $\mathrm{H} 3$ menghasilkan nilai phitung $<0.05$ sehingga $\mathrm{H} 3$ diterima atau terdapat hubungan antara profil responden terhadap kenaikan tagihan listrik. Sedangkan untuk Hipotesis $\mathrm{H} 2$ dan $\mathrm{H} 4$ berdasarkan nilai phitung $>0.05$ sehingga belum cukup bukti untuk menerima hipotesis yang diajukan sehingga pengujian Hipotesis $\mathrm{H} 2$ bermakna tidak terdapat hubungan antara perangkat tambahan yang memerlukan daya listrik terhadap kenaikan tagihan listrik, serta Hipotesis H4 bermakna tidak terdapat hubungan antara besar pulsa listrik yang dibeli terhadap kenaikan tagihan listrik. Apabila dibandingkan dengan penelitian sebelumnya, terdapat hubungan antara aktivitas perilaku sehari-hari yang banyak mengonsumsi energi listrik terhadap kenaikan tagihan listrik selama pandemi Covid-19 [2].

\section{KESIMPULAN}

Berdasarkan hasil dan pembahasan pada penelitian ini dapat disimpulkan bahwa sebanyak dua hipotesis diterima dan dua hipotesis ditolak. Hipotesis $\mathrm{H} 1$ (phitung $<0.05$ ) sehingga $\mathrm{H} 1$ diterima atau terdapat hubungan antara aktivitas perilaku harian terhadap kenaikan tagihan listrik. Hipotesis $\mathrm{H} 3$ (phitung < 0.05 ) sehingga $\mathrm{H} 3$ diterima atau terdapat hubungan antara profil responden terhadap kenaikan tagihan listrik. Sedangkan perangkat tambahan yang memerlukan daya listrik dan besar pulsa listrik yang dibeli tidak terdapat hubungan terhadap kenaikan tagihan listrik selama pandemi Covid-19 di Indonesia.

\section{REFERENCES}

[1] U. Mutumbi, G. Thondhlana, and S. Ruwanza, "Reported Behavioural Patterns of Electricity Use among Low-Income Households in Makhanda, South Africa," Sustainability, vol. 13, no. 13, p. 7271, Jun. 2021, doi: 10.3390/SU13137271.

[2] R. R. Al Hakim, Ropiudin, A. Muchsin, and F. S. Lestari, "Analisis Kenaikan Tagihan Listrik Selama Pendemi Covid-19 Berdasarkan Perilaku Konsumtif Energi Listrik di Indonesia," J. Cafe., vol. 2, no. 1, pp. 25-35, 2021, doi: 10.2020/akuntansi.v2i1.279.

[3] S. P. Williams, G. Thondhlana, and H. W. Kua, "Electricity Use Behaviour in a High-Income Neighbourhood in Johannesburg, South Africa," Sustainability, vol. 12, no. 11, p. 4571, Jun. 2020, doi: 10.3390/SU12114571.

[4] S. Snow, R. Bean, M. Glencross, and N. Horrocks, "Drivers behind Residential Electricity Demand Fluctuations Due to COVID-19 Restrictions," Energies, vol. 13, no. 21, p. 5738, Nov. 2020, doi: 10.3390/EN13215738.

[5] T. Memmott, S. Carley, M. Graff, and D. M. Konisky, "Sociodemographic disparities in energy insecurity among low-income households before and during the COVID-19 pandemic," Nat. Energy, vol. 6, no. 2, pp. 186-193, Jan. 2021, doi: 10.1038/s41560-020-00763-9.

[6] A. Abdeen, F. Kharvari, W. O'Brien, and B. Gunay, "The impact of the COVID-19 on households' hourly electricity consumption in Canada," Energy Build., vol. 250, p. 111280, Nov. 2021, doi: 10.1016/J.ENBUILD.2021.111280.

[7] P. M. R. Bento, S. J. P. S. Mariano, M. R. A. Calado, and J. A. N. Pombo, "Impacts of the COVID19 pandemic on electric energy load and pricing in the lberian electricity market," Energy Reports, vol. 7, pp. 4833-4849, Nov. 2021, doi: 10.1016/J.EGYR.2021.06.058.

[8] C. fei Chen, G. Zarazua de Rubens, X. Xu, and J. Li, "Coronavirus comes home? Energy use, home energy management, and the social-psychological factors of COVID-19," Energy Res. Soc. Sci., vol. 68, p. 101688, Oct. 2020, doi: 10.1016/J.ERSS.2020.101688.

[9] C. J. Brown and N. Markusson, "The responses of older adults to smart energy monitors," Energy Policy, vol. 130, pp. 218-226, Jul. 2019, doi: 10.1016/J.ENPOL.2019.03.063.

[10] C. M. Stein, N. J. Morris, N. B. Hall, and N. L. Nock, "Structural Equation Modelling," Methods Mol. Biol., vol. 1666, pp. 557-580, 2017.

[11] J. F. Hair, M. Celsi, D. J. Ortinau, and R. P. Bush, Essentials of marketing research (Vol. 2). New York (US): McGraw-Hill/Irwin, 2010.

[12] J. F. Hair, C. M. Ringle, and M. Sarstedt, "Partial Least Squares: The Better Approach to Structural Equation Modeling?," Long Range Plann., vol. 45, pp. 312-319, 2012, doi: 10.1016/j.Irp.2012.09.011. 
[13] J. Arifin, SPSS 24 untuk Penelitian dan Skripsi. Jakarta (ID): Elex Media Komputindo, 2017.

[14] J. F. Hair, M. Sarstedt, C. M. Ringle, and S. P. Gudergan, Advanced Issues in Partial Least Squares Structural Equation Modeling, no. 1. 2019.

[15] G. Shmueli et al., "Predictive model assessment in PLS-SEM: guidelines for using PLSpredict," Eur. J. Mark., vol. 53, no. 11, pp. 2322-2347, 2019, doi: 10.1108/EJM-02-2019-0189.

[16] A. Monecke and F. Leisch, "semPLS: Structural Equation Modeling Using Partial Least Squares," J. Stat. Softw., vol. 48, no. 3, pp. 1-32, 2012.

[17] S. Venturini and M. Mehmetoglu, "Plssem: A stata package for structural equation modeling with partial least squares," J. Stat. Softw., vol. 88, no. 1, pp. 0-35, 2019, doi: 10.18637/jss.v088.i08.

[18] R. S. Hamid and S. M. Anwar, Structural Equation Modeling (SEM) Berbasis Varian: Konsep Dasar dan Aplikasi dengan Program SmartPLS 3.2.8 dalam Riset Bisnis. Jakarta: PT Inkubator Penulis Indonesia, 2019.

[19] M. Sarstedt, C. M. Ringle, and J. F. Hair, "Partial Least Squares Structural Equation Modeling," in Handbook of Market Research, New York (US): Springer International Publishing AG, 2017. 